\title{
PERAN GANDA WANITA KARIR DALAM MANAJEMEN KELUARGA
}

\author{
Maulidyah Amalina Rizqi 1 , * \\ Program Studi Manajemen Fakultas Ekonomi dan Bisnis, Universitas Muhammadiyah Gresik, \\ Gresik, Indonesia, maulidyah@umg.ac.id \\ *Corresponding author
}

Subhan Adi Santoso ${ }^{2}$

Program Studi Pendidikan Agama Islam, Sekolah Tinggi Ilmu Tarbiyah Muhammadiyah, Lamongan, Indonesia, subhan.stitm@gmail.com

\begin{abstract}
Background - Rapid economic development and growth has encouraged women to participate in fulfilling household needs. So it is not surprising that nowadays we often find working women. Women who have a career when they are married will have a dual role, and this will have an impact on family management.
\end{abstract}

Aim - This study aims to see the dual role of career women in carrying out family management.

Diterima : 30 Desember 2021

Direview : 30 Desember 2021

Direvisi : 21 Januari 2022

Disetujui : 31 Januari 2022

Design / methodology / approach - The research method used is descriptive qualitative, with interview and observation data collection techniques.

Findings - The results of this study state that every woman who has multiple roles must be able to manage their lives well and divide it into four management types, namely time management, conflict management, self management and education management. If career women can manage these four managements well, their family life and career will be ideally organized.

Research implication - The results of this study provide knowledge to the reader to be able to manage the organization in the family, especially for families who have multiple roles.

Limitations - The focus of this study is only on women who live in urban areas.

Keywords : Women, Career, Management, Family

\begin{abstract}
Abstrak
Latar Belakang - Perkembangan dan pertumbuhan ekonomi yang pesat telah mendorong perempuan untuk berpartisipasi dalam pemenuhan kebutuhan rumah tangga. Maka tidak heran jika saat ini sering kita jumpai wanita pekerja. Wanita yang berkarir ketika sudah menikah akan memiliki peran ganda, dan hal ini akan berdampak pada manajemen keluarga.

Tujuan - Penelitian ini bertujuan untuk melihat peran ganda wanita karir dalam menjalankan manajemen keluarga.

Desain / metodologi / pendekatan - Metode penelitian yang digunakan adalah deskriptif kualitatif, dengan teknik pengumpulan data wawancara dan observasi.

Temuan - Hasil penelitian ini menyatakan bahwa setiap perempuan yang memiliki peran ganda harus mampu mengatur kehidupannya dengan baik dan membaginya menjadi empat jenis manajemen, yaitu manajemen waktu, manajemen konflik, manajemen diri dan manajemen pendidikan. Jika wanita karir dapat mengelola keempat manajemen ini dengan baik, kehidupan keluarga dan karir mereka akan tertata secara ideal.

Implikasi penelitian - Hasil penelitian ini memberikan pengetahuan kepada pembaca untuk dapat mengelola organisasi dalam keluarga, khususnya bagi keluarga yang memiliki peran ganda.

Keterbatasan - Fokus penelitian ini hanya pada perempuan yang tinggal di perkotaan.
\end{abstract}

Kata kunci : Wanita, Karir, Manajemen, Keluarga 


\section{PENDAHULUAN}

Dari laman Jatim.Inews.id disampaikan bahwa Jumlah Pertalakan di Gresik Tahun 2020 tembus mencapai 1068 kasus, dengan beraneka permasalahan yang menjadi sumbernya seperti selingkuh, minuman keras, berjudi, pergi tanpa kabar, dibui, hingga kekerasan 4 dalam rumah tangga. Selain itu ada juga lantaran cacat badan, perselisihan terus menerus, kawin paksa, murtad dan faktor ekonomi. Menurut Hakim Pengadilan Agama Gresik, Sofyan Zefri mengatakan, perceraian terjadi pada kisaran usia produktif dari 25 sampai 40 Tahun. "Perceraian pada masa pandemi Covid-19 dikarenakan masalah ekonomi dengan Jumlah 630 kasus. Karena pemicu terbesarnya adalah faktor ekonomi, hal inilah yang memotivasi para wanita untuk bekerja demi membantu keuangan keluarga.

Perkembangan dan pertumbuhan ekonomi dalam beberapa dekade ini telah terjadi dengan sangat pesat. Situasi ini menuntut wanita untuk ikut serta dalam pemenuhan kebutuhan keluarga dari sektor finansial. Kondisi ini tidak awam lagi jika kita sering menjumpai wanita yang bekerja. Dalam era sekarang, dimana ilmu dan teknologi berkembang dengan pesat, menyebabkan semakin terkikisnya sekatsekat yang memisahkan antara pria dan wanita untuk bekerja. Hampir seluruh kegiatan/ pekerjaan pria dapat dilakukan oleh para wanita.
Pada era globalisasi ini keterlibatan perempuan sangat esensial. Hampir tidak terlihat lagi perbedaan antara laki-laki dengan perempuan. Keduanya memiliki hak, status, peranan, dan kesempatan untuk berkembang dan berkontribusi dalam struktur masyarakat modern. Fenomena tentang wanita karier seakan-akan tidak dapat di bendung lagi. Hal inilah yang sering digaungkan didalam masyarakat bahwa emansipasi wanita benar-benar ada dan terwujud dengan sangat jelas.

Dahulu wanita identik dengan menjadi ibu rumah tangga, yang bergelut dengan kegiatan seputar rumah tangga saja, seperti melayani suami, mengurus dan merawat anak. Seiring dengan berkembangnya zaman peran wanita juga mengalami regulasi. Wanita tidak lagi mengurus seputar rumah tangga saja melainkan memilih terjun pada dunia kerja untuk berkarier. Permasalahan yang terjadi yaitu lebih memilih untuk bekerja, dibandingkan menjadi ibu rumah tangga, sehingga berperan ganda mengurus rumah tangga dan bekerja akhirnya menimbulkan permasalahan baru.

Selain dituntut untuk memenuhi kewajibannya dalam rumah tangga, ia juga memiliki beban untuk menyelesaikan tugas dan tanggung jawabnya di dalam pekerjaan sebagai bentuk untuk membangun karir. Menjalani kedua peran tersebut tentu tidaklah mudah, wanita yang berperan ganda tentu harus bisa membagi waktu antara keduanya. 
Keluarga juga dapat dikatakan sebuah organisasi yang harus di atur, di tata secara rapi dan tersistem dengan baik. Keluarga juga membutuhkan manajemen agar dapat terwujudnya keluarga yang harmonis dan sehat. Bagi wanita yang menjalankan peran ganda secara bersamaan juga tidak lah mudah. Tuntutan pekerjaan yang harus di selesaikan tepat waktu (deadline) juga membuat mereka 5 harus dapat membagi waktu untuk keluarganya. Meskipun mereka dapat bertemu dengan keluarga setiap harinya akan tetapi waktu dan perhatian yang di berikan tidak dapat sepenuhnya.

Wanita yang berasal dan berdomisili dari perkotaan mendominasi menjadi pekerja. Karena perekonomian diperkotaan yang tinggi dan menuntut mereka untuk bekerja untuk membantu perekonomian keluarga. Saat mereka berkeluarga maka peran mereka menjadi ganda, yakni menjadi istri, ibu dan juga pekerja. Seseorang yang berperan ganda banyak yang mengalami stress kerja ataupun stress dalam keluarga. Karena lelah yang mereka rasakan menjadi salah satu pemicu hal tersebut. Jika mengalami hal tersebut maka dibutuhkan manajemen keluarga yang harus tertata dengan baik.

Berdasarkan informasi yang penulis dapatkan, problematika yang sering terjadi disekitar kita adalah terkait kekacauan manajemen keluarga yang bermuasal dari manajemen waktu para wanita karir. Para wanita yang berkeluarga di hadapkan pada permasalahan pembagian waktu antara keluarga dan pekerjaan. Manajemen keluarga dibutuhkan dalam kehidupan berumah tangga, terutama pada pasangan yang memiliki karir masing-masing.

Terutama bagi para wanita yang berperan ganda, mereka harus dapat menerapkan manajemen yang baik agar mereka tidak menghadapi kekacauan dan stress dalam kehidupan mereka. Karena jika para wanita yang berkarir mengalami kekacauan dalam manajemen waktu maka berdampak pada manajemen keluarga dan produktivitas mereka dalam karirnya.

Wanita yang berkarir harus dapat mengatur pembagian waktu antara urusan keluarga dan keperluan pekerjaan. Karena mengelola manajemen keluarga tidaklah mudah, hal ini yang diungkapkan oleh Rahman (2018) bahwa peran ganda bagi wanita karier tidaklah mudah, tetapi responden menunjukkan bahwa wanita karier dapat melewati perannya tersebut dengan baik, melalui pola asuh demokratis, dan memberikan wawasan kepada anak dengan pembekalan agama serta dalam pengawasan orang tua. Meskipun dalam pengaturan waktu menjadi faktor penghambat menjadi ibu, istri, dan pekerja, agar tetap menjalankan tanggung jawab sebgai ibu, istri, dan pekerja.

Penelitian ini bertujuan untuk melihat peran ganda wanita karir dalam melaksanakan manajemen keluarga. Fokus penelitian ini hanya terhadap wanita yang 
tinggal diarea perkotaan dan berperan ganda menjadi ibu rumah tangga maupun pekerja.

\section{TINJAUAN PUSTAKA}

\section{Peran Wanita Karier}

Karier adalah urutan aktifitas tentang pekerjaan serta perilaku, nilai-nilai dan aspirasi sesorang selama perjalanan hidup seseorang tersebut (Simamora, 2007). Uraian di atas, dapat disimpulkan karier adalah untaian pekerjaan seseorang dalam kurun waktu tertentu berdasarkan nilai, perilaku, dan sikap serta motivasi bekerja dengan mencapai prestasi gemilang. Berkarier lebih identik dengan pekerjaan seorang wanita yang dilakukan di luar rumah demi membantu perekonomian keluarga atau istilah sekarang yaitu kesetaraan gender. Namun realitanya pria mempunyai peluang bekerja lebih banyak dibandingkan dengan wanita, terutama urusan pekerjaan atau berkarier. Sedangkan pria bisa bekerja di luar rumah karena mempunya tanggung jawab sebagai kepala rumah tangga dibandingkan dengan Wanita seyogyanya hanya mengurus keadaan rumah selama suami bekerja.

(Anshary, 2002) Wanita karir adalah, wanita yang melakukan aktivitas di luar rumah dalam membantu pemasukan ekonomi keluarga dan menggapai prestasi yang diharapkan. Peran wanita karier bersamaan dengan ini wanita cenderung sebagai istri dan ibu rumah tangga, yang membedakan antara wanita karier yakni memiliki peran tambahan atau peran ganda yaitu sebagai pekerja yang bertanggungjawab pada pekerjaannya. Kedua peran tersebut harus dilaksanakan dengan sebaik mungkin dan menjadikan keluarga sebagai prioritas.

\section{Ciri-ciri Wanita Karier}

Berbagai pencapaian telah dilakukan oleh wanita karier, bukan itu saja mereka juga memiliki tingkat energi yang tinggi, daya tahan tubuh dan kesehatan yang baik (Istiyanto, 2007). Serta, wanita karier memiliki dorongan yang kuat dan keuletan dalam mengatasi permasalahan dan mampu memiliki konsistensi dalam ketetapan hati.

\section{Faktor Pendorong Wanita Berkarier}

Faktor-faktor yang mendorong atau memotivasi seorang wanita untuk berkarir di luar rumah antara lain :

\section{Faktor Pendidikan}

Para wanita yang telah menyelesaikan pendidikannya di perguruan tinggi dan meraih gelar sarjana pada umumnya sudah tentu tidak akan mau atau tidak betah tinggal di rumah saja tanpa melakukan aktivitas apapun. Para wanita akan mencari lowongan kerja untuk meniti karir yang sesuai dengan disiplin keilmuan yang mereka miliki. Banyak wanita terdidik dewasa ini tidak puas hanya berpangku tangan menjalankan perannya di rumah saja. Dalam hal ini wanita juga sebagaimana halnya pria ingin pula berperan serta 
membuktikan kemampuannya (Achir, 1985).

\section{Faktor Ekonomi}

Kerapkali persoalan ekonomi yang dijadikan perdebatan oleh pakar tentang Wanita karir dengan berbagai alasan yaitu sebagai bentuk membantu suami dalam hal mencukupi kebutuhan seharihari.Terlebih lagi pada masa ini, harga kebutuhan sehari-hari semakin banyak jumlah pengeluarannya. Keadaan ini sangat merangsang para wanita untuk ikut dalam kegiatan industri dan hidup di daerah perkotaan dan sekitarnya. Dorongan dari dunia industri membolehkan Wanita bekerja dan setara dengan pekerjaan yang dikerjakan oleh kaum pria sebagai alasan untuk membantu meringankan beban keluarga, serta memiliki penghasilan sendiri, dan kurang tertarik bekerja menjadi petani.

\section{Faktor Sosial}

Desiree (1993) Tuntutan zaman dapat merubah pola pikir wanita lebih memilih bekerja di luar rumah demi mengejar karir yang diharapkannya. Seringkali bukan semata-mata untuk mencukupi kebutuhan hidup saja wanita harus bekerja, tetapi juga didorong oleh faktorfaktor lainnya seperti untuk meningkatkan status sosial.

4. Kebutuhan aktualisai diri

Merupakan profesi atau pun karir, sebagai pilihan menarik dalam mengekpresikan rangkaian ilmu yang diperoleh selama dibangku sekolah atau kuliah, para wanita di jaman sekarang ini lebih terbuka dalam meraih kesempatan yang sama pada wanita untuk meraih jenjang karir yang tinggi.

\section{Peran Ganda Wanita}

Peran ganda merupakan dua peran yang dijalankan oleh seorang saja dalam menjalankan suatu tugas yang memang sudah menjadi hal yang dikerjakannya (bekerja) dan juga salah satu peran itu telah menjadi kodrat yang memang telah melekat dari dahulu pada diri dan tanggung jawabnya (ibu rumah tangga) di dalam sebuah keluarga. Dalam keluarga konvensional, suami bertugas mencari nafkah dan istri yang mengurus rumah tangga (Suparman, 2017). Tetapi kini, dengan tumbuhnya kesempatan bagi Perempuan bersuami untuk bekerja, pada pola kekeluargaan segera berubah dan muncul apa yang disebut sebagai dualisme karir.

Dualisme (persamaan karir) karir terjadi bila suami maupun istri sama-sama bekerja dan mengurus rumah tangga secara bersama pula. Di dalam hubungannya dengan posisi masing-masing, setiap pasangan suami istri memiliki cara yang berbeda di dalam mengatur peranannya dalam pekerjaan dan rumah tangga. Perempuan yang bekerja secara part time umumnya menganggap bahwa pekerjaan 
hanyalah sekedar hobbi dan hanya menduduki prioritas kedua dibawah kepentingan keluarga. Tetapi dalam keluarga dualism karir egalitarian, suami istri bekerja tidak hanya sekedar mencari nafkah tetapi juga dalam persaingan untuk mendapatkan posisi yang sama dalam pengambilan keputusan serta berbagai aktivitas dalam keluarga.

\section{Manajemen dalam Keluarga}

Sebuah keluarga ibarat sebuah organisasi yang harus dijaga dan juga dikelola untuk mencapai tujuan bersama. Terdapat beberapa manajemen yang ada dalam sebuah keluarga. Berikut lima manajemen yang harus dikelola oleh organisasi keluarga

1. Manajemen Keuangan

Pramudhita (2012) mengatakan bahwa Perencanaan Keuangan Pribadi atau Keluarga adalah cara mencapai tujuan keuangan seseorang atau keluarga melalui proses manajemen keuangan. Tujuan itu secara umum sebagai berikut:
a. Proteksi (insurance planning)
b. Investasi dan tabungan (investment planning)
c. Pensiun (retirement planning)
d. Pendidikan (education planning)
e. Pajak Penghasilan (income tax planning)

f. Warisan (estate planning)

Perencanaan diperlukan agar kita dapat mencapai tujuan keuangan secara menyeluruh dan mencakup seluruh siklus kehidupan kita, dari sekarang hingga akhir nanti. Perencanaan keuangan yang benar dan matang membutuhkan disiplin dan kontrol yang tepat. Untuk itu, kita mempelajari ilmu perencanaan keuangan pribadi dan mempraktekkannya dalam rencana keuangan sendiri.

2. Manajemen konflik

Manajemen konflik adalah kemampuan individu untuk mengelola konflik-konflik yang dialaminya dengan cara yang tepat, sehingga tidak menimbulkan komplikasi negatif pada kesehatan jiwanya maupun keharmonisan keluarga. Ada beberapa jenis konflik yang dialami oleh individu. Jika kita meninjau dari sumber timbulnya konflik maka dapat dibedakan menjadi Konflik yang bersumber dari diri sendiri, sering disebut dengan konflik internal. Konflik yang bersumber pada lingkungan. Lingkungan dapat dibagi menjadi lingkungan keluarga, dan lingkungan diluar keluarga (tetangga, sekolah, teman, massa, tempat kerja, dll).

3. Manajemen Pendidikan Agama Dalam kehidupan keluarga, masyarakat dan negara sangat diperlukan ilmu pendidikan terutama ilmu pendidikan Islam. Ilmu ini sangat penting untuk bimbingan atau panutan pendidik kepada anak didiknya agar tumbuh secara wajar dan kepribadian muslim. 
Berdasarkan penegasan di atas maka pendidikan Islam perlu mendapat perhatian dari semua pihak terutama dalam hal manajemen pendidikannnya. Pendidikan yang baik menjadi tolak ukur suatu Negara dalam kemajuannya terutama dalam Islam. Manajemen dalam Islam ini diperlukan untuk mencapai tujuan bersama dan meningkatkan kualitas umat dari keterbelakangan materi, moral dan spiritual.

4. Manajemen Kesehatan

Manajemen kesehatan merupakan tingkat kesehatan masyarakat yang di tujukan atau di pusatkan keluarga sebagai unit atau kesatuan yang di rawat dengan sehat sebagai tujuan melalui perawatan sebagai saran atau penyalur. Keluarga di jadikan unit pelayanan karena masalah kesehatan keluarga dan akan mempengaruhi antara sesama anggota keluarga dan akan mempengaruhi juga keluarga di sekitarnya atau secara keselurah

5. Manajemen Pendidikan

Esensi pendidikan umum, mencakup dua dimensi yaitu dimensi pedagogis dan dimensi subtantif. Dimensi pedagogis adalah proses menghadirkan situasi dan kondisi yang sebanyak mungkin anak didik terundang untuk memperluas dan memperdalam dimensi substansif. Pendidikan umum dilaksanakan dalam lingkungan keluarga, sekolah dan masyarakat. Keluarga merupakan salah satu lembaga yang mengembang tugas dan tanggung jawab dalam pencapaian tujuan pendidikan umum. Tujuan esensial pendidikan umum adalah mengupayakan subyek didik menjadi pribadi yang utuh dan terintegrasi.

\section{METODOLOGI PENELITIAN}

Penelitian ini menggunakan metode kualitatif dengan pendekatan berparadigma Fenomologi. Menurut Bogdan dan Taylor dalam Moleong (2006) mengatakan bahwa Metode Penelitian Kualitatif sebagai prosedur penelitian yang menghasilkan data deskriptif berupa kata-kata tertulis atau lisan dari orang dan perilaku yang dapat diamati. Semua yang dikumpulkan berkemungkinan menjadi kunci terhadap apa yang diteliti. Fathan (2011) menyatakan bahwa penelitian kualitatif berasaskan latar "alamiah" yang berarti kajian dilakukan bersifat holistik pada suatu gejala individu atau kelompok masyarakat tertentu dalam konteks tertentu. Alasan menggunakan metode ini adalah peneliti akan terlibat langsung terhadap apa yang diteliti dan juga melibatkan diri terhadap obyek yang diteliti, tetapi peneliti tidak perlu ikut campur untuk melakukan perubahan di dalamnya tentang apa yang ada dan terjadi dalam subyek dan konteks penelitian.

Penelitian ini menggunakan desain kasus tunggal holistic, desain ini untuk melakukan eksplorasi secara mendalam 
(spesifik) tentang kejadian tertentu atau beberapa peristiwa dari sebuah fenomena. Penelitian ini hanya berfokus pada sejumlah kecil kejadian yang diselidiki secara mendalam dalam satu rentang waktu, dan dalam penelitian ini hanya terfokus pada wanita karir yang tinggal di area perkotaan Kabupaten Gresik. Penelitian ini menggunakan dua macam teknik pengumpulan data, yaitu: Metode Wawancara dan Metode Observasi atau Pengamatan. Sugiyono (2008) dapat dilakukan dengan beberapa tahapan diantaranya: "Mengumpulkan data dengan analisis data, hasil pengumpulan data tersebut tentu saja perlu direduksi (data reduction), yaitu dengan mengikhtiarkan hasil pengumpulan data selengkap mungkin dan memilahnya ke dalam satuan konsep tertentu, kategori tertentu dan tema tertentu. Seperangkat hasil reduksi data juga perlu diorganisasikan ke dalam satu bentuk tertentu (display data) sehingga terlihat sosok secara lebih utuh, sajian data tersebut sangat diperlukan untuk memudahkan upaya pemaparan dan penegasan kesimpulan (conclusion)".

Dalam penelitian kualitatif rawan sekali data yang diperoleh terjadi bias. Hal tersebut wajar adanya, karena yang dicari adalah kata-kata sehingga tidak mustahil terdapat kata-kata keliru yang tidak sesuai antara yang di katakan dengan keadaan yang sesungguhnya. Guna menjaga keabsahan data dalam penelitian, maka digunakan pemeriksaan keabsahan data dengan menggunakan metode member check. Melakukan pengecekkan atau penyesuaian data terhadap informan.

\section{HASIL DAN PEMBAHASAN}

Sebelum membahas hasil penelitian ini mari kita mengulas tentang peran ganda terlebih dahulu, menurut Ramadani (2016) mengatakan bahwa peran ganda adalah perempuan yang memiliki dua pekerjaan yang dilakukan dengan satu waktu yaitu bekerja di rumah dan di luar rumah dan dampak yang ditimbulkan dengan adanya peran ganda meliputi timbulnya kebiasaan yang kurang baik dalam pekerjaan seperti disiplin kerja menurun, kepuasan kerja yang rendah, turn over, psikologis keluarga dan psikologis pribadi pelaku peran ganda yang terpengaruh oleh peran ganda.

Hasil penelitian ini dapat di sampaikan bahwa wanita yang memiliki peran ganda dalam keluarga sebagai ibu rumah tangga dan juga pekerja. Para wanita yang memiliki peran ganda pasti banyak menghadapi konflik, diantaranya konflik dunia kerja dan konflik rumah tangga. Namun, dari penelitian ini dihasilkan bahwa para wanita yang memiliki peran ganda dapat mengelola manajemen keluarga dan manajemen Diri.

\section{Manajemen Waktu}

Para informan yang memiliki peran ganda mereka akan dihadapkan dengan problematika manajemen waktu yang harus 
dikelola dengan baik agar dapat menjalankan dua peran tersebut dengan semaksimal mungkin. Para informan menyatakan bahwa mereka harus membagi waktu antara pekerjaan di rumah dan juga pekerjaan di kantor.

Informan penelitian mendominasi dengan menjawab bahwa mereka akan mendahulukan peran mereka sebagai ibu rumah tangga daripada pekerjaan mereka. Karena mereka meyakini bahwa kodrat wanita adalah sebagai ibu dan juga istri yang harus dapat menyelesaikan tugas utama mereka sebagai ibu dan istri. Banyak dari para informan mengakui bahwa mereka harus bangun lebih awal untuk mempersiapkan kewajibannya dalam rumah tangga, seperti menyiapkan anak sekolah, masak dan juga membersihkan rumah. Setelah itu mereka baru dapat berangkat kerja, bahkan mereka harus tergesa-gesa dalam perjalanan agar segera sampai di kantor tepat waktu. Tidak hanya itu mereka juga terkadang mengabaikan keselamatan berkendara agar segera sampai tujuan.

Para wanita yang memiliki peran ganda harus membagi waktu untuk keluarga dan bekerja dengan bangun lebih awal membuat mereka harus terkantuk-kantuk saat berada di kantor atau di tempat kerja mereka. Ada beberapa informan yang menyampaikan bahwa saat mereka berada di jam kerja juga tidak sedikit yang mengambil waktu kerjanya untuk menyelesaikan tugas mereka sebagai ibu dengan harus menjemput anak- anak mereka pulang sekolah dan mereka akan menggantinya dengan menggunakan jam istirahat untuk menyelesaikan pekerjaan yang tadi ditinggalkannya.

Wanita dengan peran ganda harus mampu mengelola waktu dengan baik agar dapat mendistribusikan waktunya untuk keluarga dan juga pekerjaan. Salah satunya dengan cara mengawali aktivitas lebih awal daripada wanita yang tidak memiliki peran ganda. Mereka juga harus merelakan waktu istirahat mereka terkurangi untuk bisa menyelesaikan kewajiban wanita yang berumah tangga. Bahkan dapat dikatakan bahwa wanita yang memiliki peran ganda hanya akan memiliki waktu luang di hari libur kerja bersama keluarga untuk bisa menikmati family's time.

\section{Manajemen Konflik}

Saat seseorang memiliki peran ganda maka tidak menutup kemungkinan bahwa mereka memiliki konflik yang beraneka ragam, konflik dengan dunia kerja dan juga dengan keluarga. Disaat konflik itu terjadi maka seharusnya setiap orang dapat menyelesaikannya, namun penyelesaian tersebut membutuhkan waktu. Terkadang pada waktu penyelesaian tersebut dapat menimbulkan konflik baru.

Hal ini terjadi pada salah satu informan dalam penelitian ini. Kita sebut dia "nani" yang memiliki konflik dengan keluarganya (suami) yang mana dia berusaha untuk menyelesaikannya namun saat dia berusaha 
menyelesaikan konflik tersebut produktivitasnya di tempat kerja menurun, dan akhirnya menjadikan hal tersebut konflik baru di tempat kerja. Karena secara tidak langsung wanita tersebut terus berfikir tentang permasalahan rumah tangganya meski dia berada pada lingkungan kerja.

Terkadang para wanita yang berperan ganda akan berkonflik dengan dirinya sendiri, karena di satu sisi ingin membantu perekonomian keluarga dan disisi lain mereka harus meninggalkan putra putri mereka di rumah dengan asisten rumah tangga atau di tempat penitipan anak. Dilema seperti ini yang sering terjadi kepada wanita yang masih memiliki anak dibawah 12 tahun.

Semua manusia pasti memiliki konflik masing-masing yang pastinya jenis konfliknya berbeda-beda. Namun bagi manusia yang memiliki peran ganda terutama bagi wanita harus dapat memposisikan diri untuk profesionalitas diri. Jadi saat konflik terjadi memang harus diselesaikan tapi jangan mengaitkan konflik yang ada di dunia kerja dengan konflik yang ada di dunia rumah tangga begitu sebaliknya.

Saat para wanita yang berperan ganda memiliki masalah keluarga maka harus memilah dan menyaringnya agar tidak mengganggu pekerjaan sehingga tidak menimbulkan konflik yang baru. Karena tidak sedikit para wanita membawa unsur perasaan kedalam setiap kegiatan yang mereka lakukan.

\section{Manajemen Diri}

Pengelolaan seluruh point diatas pasti membutuhkan manajemen diri yang baik, karena untuk bisa mengatur waktu bagi rumahtangga, pekerjaan dan juga untuk diri sendiri membutuhkan controlling yang baik. Maka dari itu membutuhkan yang namanya manajemen diri, jika seseorang memiliki manajemen diri yang baik maka mereka akan mudah untuk mengelola hal-hal kecil lainnya. Pengelolaan diri sama halnya dengan EQ (Emotional Quotients), jika manusia memiliki EQ yang baik maka mereka akan mudah untuk melakukan manajemen hidup yang baik pula.

Saat seseorang dapat me-manage diri dengan baik maka akan dapat menyelesaikan konflik yang terjadi dengan baik pula, begitu pula dengan pengaturan/ manajemen waktu. Para wanita yang memiliki peran ganda harus dengan pintar dan cermat dalam mengelola diri mereka, karena ada kehidupan yang bergantung pada mereka, yakni kehidupan keluarga.

Beberapa informan menyatakan sedikit mengalami kesulitan untuk mengatur emosional atau diri mereka disaat rasa jenuh dan lelah itu mendera. Mereka mengaku bahwa mereka membutuhkan hiburan atau waktu istirahat. Sedangkan yang terjadi pada kebanyakan wanita yang berperan ganda mereka mengaku bahwa kebanyakan 
pada hari libur mereka gunakan untuk menyelesaikan tugas-tugas rumah yang belum sempat dikerjakan. Bisa dikatakan tidak ada hari libur bagi wanita yang memiliki peran ganda.

\section{Manajemen Pendidikan}

Salah satu pendekatan yang dapat dilakukan adalah keterbukaan agar dapat tumbuh sebuah kepercayaan diri dalam menghadapi berbagai hal. Pendidikan yang dimaksud menurut para informan berasal dari 2 sudut pandang. Pertama, manajemen yang ditetapkan untuk pendidikan anakanak. Terutama seorang wanita yang berperan sebagai ibu harus bisa mendidik anak-anaknya. Karena ibu merupakan pendidikan pertama bagi seorang anak.

Menurut para informan yang memiliki anak dengan status pelajar harus dihadapkan pada dilema kondisi saat ini, yakni kondisi pendidikan secara virtual. Dimana untuk mendampingi anak yang sedang bersekolah secara virtual para wanita tersebut tidak dapat menerapkannya. Tidak sedikit dari informan ini yang menyatakan mereka harus membayar seseorang untuk mendampingi sekolah anak, karena jika pendidikan dilaksanakan secara langsung (offline) maka para wanita karir tersebut cukup menitipkan pada pihak sekolah hingga jam pulang.

Ada beberapa informan yang mengaku bahwa sengaja memilih sekolah anak secara fullday agar memudahkan mereka untuk antar jemput sekolah. Jadi mereka menjemput anak-anak mereka disaat jam kerja selesai dan mengantar mereka sebelum jam masuk kerja. Disinilah peran seluruh anggota keluarga dibutuhkan untuk bisa terus bersinergi satu dengan yang lainnya.

Kedua, para wanita yang berkarir lebih memilih dua peran untuk bisa memanfaatkan hasil pendidikannya di dunia kerja daripada hanya sebagai ibu rumah tangga yang hanya berdiam diri dirumah. Hal ini sesuai informasi dari raywhite.co.id/news (2021) bahwasanya mereka tidak ingin ijasahnya hanya sebagai penghasil tittle saja. Informan juga menyatakan jika mereka bertittle dan bekerja maka mereka memiiki kepercayaan diri lebih daripada wanita lainnya serta dapat berfikir positif dalam berbagai hal. Jadi, pendidikan tersebut tidak hanya didapatkan tetapi juga disalurkan melalui dunia kerja.

\section{KESIMPULAN}

Kesimpulan yang dapat diambil dari hasil dan juga pembahasan diatas bahwa setiap wanita yang memiliki peran ganda harus mampu mengelola kehidupan mereka dengan membaginya menjadi tiga manajemen.

1. Manajemen Waktu

Pembagian waktu yang baik bagi wanita karir antara keluarga dan juga pekerjaan akan membuat kehidupan lebih baik, karena semuanya akan tertata dan 
waktu yang didistribusikan juga akan adil dan merata.

2. Manajemen Konflik

Wanita yang berperan ganda harus dapat mengelola konflik, terutama pengelolaan perasaan pula. Karena wanita lebih mendominasi perasaan saat menyelesaikan sebuah konflik. Sebagai wanita karir juga harus profesional dalam bekerja, tidak dapat mencampuradukkan antara konflik rumah tangga dengan pekerjaan. Meski kenyataannya sulit tetapi hal itulah yang harus dilakukan.

3. Manajemen Diri

Pengelolaan diri yang baik akan berdampak pada banyak hal, seperti produktivitas kerja dan juga manajemen keluarga juga akan baik pula. Setiap wanita yang berperan ganda harus dapat mengelola diri dengan baik.

4. Manajemen Pendidikan

Pendidikan kepada anak harus tetap diberikan dengan baik agar peran wanita sebagai ibu tetap dapat dilakukan. Pemanfaatan pendidikan formal seorang wanita juga dapat diterapkan agar dapat tumbuh kepercayaan diri dan juga tata cara berfikir yang positif.

\section{IMPLIKASI PENELITIAN}

Hasil penelitian ini dapat memberikan pengetahuan kepada pembaca terutama wanita dengan peran ganda untuk dapat mengelola organisasi/ manajemen keluarga, khususnya bagi keluarga yang memiliki peran ganda. Terutama bagi wanita yang memiliki peran ganda sebagai ibu, istri dan juga pekerja. Mereka harus dapat membagi diri untuk keluarga dan juga karir.

\section{ACKNOWLEDGEMENT}

Terwujudnya penelitian ini tidak hanya jerih paya peneliti tetapi juga banyak pihak, terutama para informan yang telah rela dan bersedia meluangkan waktu untuk berbagi ilmu dan pengalaman tentang bagaimana cara mereka mengelola keluarga ditengah kesibukan mereka untuk bekerja. Semoga dari penelitian ini dapat dijadikan ilmu tambahan bagi para wanita yang memiliki peran ganda sebagai wanita karir dan juga ibu rumah tangga guna mewujudkan manjemen keluarga yang baik.

\section{DAFTAR PUSTAKA}

Achir, Yaumi Agoes, Wanita Dan Karya Suatu Analisa Dari Segi Psikologi dalam Emansipasi Dan Ganda Wanita Indon esia, Jakarta : UI Press. 1985.

Anshary, Hafiz A,Z dan Huzaimah T, Yanggo (ed ), Ihdad Wanita Karir dalam Problematika Hukum Islam Kontemporer (II), Cet. III. Jakarta: Pustaka Firdaus, 2002.

Desiree, Auraida dan Jurfi Rizal (Ed.), Masyarakat dan Manusia Dalam Pembangunan, Jakarta: Pustaka Sinar Harapan. 1993. 
Ernawati, Siti. 2016. Peran Ganda Wanita Karier (Konflik Peran Ganda Wanita Karier ditinjau dalam Prespektif Islam. Jurnal Edutama Volume 2, Nomor 2, 2 Januari 201

Fatchan, Ahmad. Metode Penelitian Kualitatif Beserta Contoh Proposal, Tesis Dan Disertasi. Surabaya. Jenggala Pustaka Utama. 2011.

Istiyanto, S B. 2007. Pentingnya Komunikasi Keluarga : Menelaah Posisi Ibu Antara Menjadi Wanita Karir atau Penciptaan Keluarga Berkualitas. Jurnal Komunika, Volume 1 No. 2 JuliDesember 2007.

Jacinta F. Rini, Wanita bekerja, Jakarta : E-psikolgi.com

Maria, Stella, Dampak Industrialisasi Terhadap Perempuan dalam : Wanita Indonesia ...,. 30

Moleong, Lexy J. Metodologi Penelitian Kualitatif, Edisi 22. Bandung.PT. Remaja Rosdakarya. 2006.

Prijosaksono, A. 2001. Self Management Series. Jakarta : Gramedia.

Rahman, Ana septia. 2018. Peranan Wanita Karier Dalam Keluarga, Pola Asuh Dan Pendidikan Anak (Studi Kasus Pada Wanita Karier Pada Jl. Anggrek Rt 002/018 Pondok Benda Pamulang Tangerang Selatan). JENIUS, Jurnal Ilmiah Sumber Daya manusia, Volume.01 Nomor 02, tahun 2018.

Rosita, Sry. 2012 Pengaruh Konflik Peran Ganda dan Stress Kerja terhadap Kinerja Dosen Wanita di Fakultas Ekonomi Universitas Jambi. Jurnal Manajemen Bisnis, Volume 2, Nomor 2, Oktober 2012.

Simamora, Henry. Manajemen Sumber Daya Manusia. STIE YKPN. Yogyakarta. 2007

Sugiyono. Methode Penelitian Kuantitatif, Kualitatif, R dan D. Alfabeta. Bandung. 2008.

Suparman. Peran Ganda Istri Petani (Studi Kasus di Desa Perangian Kecamatan Baraka Kabupaten Enrekang), EDUMASPUL: Jurnal Pendidikan. Volume 01. No. 22017.

Thontowi, Zulkifli Syauqi. Dkk, 2019. Manajemen Pendidikan Keluarga perspektif Al-Qur'an menjawab Urban Middle class milenial, Edukasi Islami : Jurnal Pendidikan Islam. Volume 08. No.12019.

Urban Middle class milenial, Edukasi Islami : Jurnal Pendidikan Islam. Volume 08. No.12019.

https://angga16pramudhita.wordpress.com/2012/03/03/sistem-manajemen-dalamkeluarga/

https://jatim.inews.id/berita/pandemi-covid-19-angka-perceraian-di-gresik-melonjak

https://www.kompasiana.com/ameliaamanda/5d50b9a30d82304f5d773379/wanita-karirinterpretasi-perempuan-modern-masa-kini

https: / / www.raywhite.co.id/news / 152944wanita-karir-adalah-wanita-yang-luar-biasa 